\title{
13 \\ The Renaissance of the Melanesian Spearhead Group
}

\section{Tess Newton Cain}

Although the Melanesian Spearhead Group (MSG) has been in existence for more than 25 years, it is only recently that it has come to prominence within the sub-region and more widely. The recent renaissance of the MSG would appear to represent a blend of two things. First is the maturing diplomacy of the Melanesian states, both in terms of the increased number of relationships formed within the sub-region and the evidence of increased sophistication of those engagements, particularly in relation to trade and economic integration. Secondly, the recent prominence of this grouping is indicative of a perceived failure of pan-regional diplomacy, including (but not limited to) the isolation of Fiji in the 2006-2014 period.

This chapter presents the evolution and work of the MSG within a wider consideration of the significance of sub-regional groupings in the Pacific. It then considers what diplomatic opportunities and challenges may face the MSG with reference to the impacts of internal diplomacy on the ability of the group to act cohesively within the region and on the wider international stage. 


\section{The Background to the Recent Renaissance of the MSG}

The MSG is a prominent example of a sub-regional grouping among what looks to be an increasing number of such initiatives. There are, broadly speaking, two subsets of sub-regional groups: those that are based on geographical proximity and/or cultural affinity, and those that are based on the pooling of resources to address service delivery or other policy issues.

There are three sub-regional groups that align broadly with the most widely accepted cultural demarcations in the region as a whole. The memberships of these groups comprise sovereign and non-sovereign entities. While this indicates a degree of diplomatic innovation, it can present challenges in terms of engaging in wider arenas, whether at the regional or global levels.

The Micronesian Chief Executives Summit (MCES) was convened for the first time in 2003. It brings together the political leadership of the Commonwealth of the Northern Marianas, the Territory of Guam, the Federated States of Micronesia (Yap, Kosrae, Pohnpei, and Chuuk), the Republic of Marshall Islands, and the Republic of Palau (ROP). The most significant achievement of this group to date is the establishment of the 'Micronesia Challenge', which has environmental issues and the management of natural resources as its primary areas of focus.

The Polynesian Leaders Group (PLG) was established largely in response to the growing presence of the MSG. It comprises the leaders of eight states and territories: American Samoa, Cook Islands, French Polynesia, Niue, Samoa, Tonga, Tuvalu and Tokelau. To date, it has been the least active of these groupings, with its focus being more on establishing and maintaining cultural ties than on economic or political endeavours. However, ahead of its most recent gathering in Auckland in 2015, it was announced that the group would be focusing on the enforcement of fisheries management (Radio New Zealand 2015).

The MSG is generally acknowledged to be the most established and dynamic of this set of sub-regional groupings. The MSG was established in 1988 and obtained recognition as an international organisation in 2007. Its current membership is the sovereign states of Fiji, Papua New Guinea, Solomon Islands and Vanuatu plus the Front de Libération Nationale Kanak et Socialiste (Kanak and Socialist National Liberation Front (FLNKS)), a pro-independence movement from New Caledonia. The FLNKS has chaired the MSG since June of 2013 and will hand over chairing responsibility to the government of Solomon Islands during 2015. It has a secretariat located in Port Vila, Vanuatu and, in recent years, has been increasingly active both politically and economically. 
Pooled service delivery at the pan-regional level is fraught with challenges of varying types and there are some indications that they are easier to overcome by operating sub-regionally (Dornan and Newton Cain 2014). This form of sub-regional activity does not necessarily have to be formulated by reference to geographic proximity or cultural affinity. The most significant grouping of this type is (currently) the Parties to the Nauru Agreement (PNA). Its members are particularly concerned with management of fisheries in order to maximise economic return and promote sustainability and appear to have been more successful (at least on the former issue) than the larger Forum Fisheries Agency (ADB 2014).

It is not surprising that a grouping with the longevity of the MSG has undergone numerous changes in its lifetime. There have been changes to the membership, to the activities it has undertaken, and to its relative importance, whether to its members or within the wider region. Here, I will examine some of the milestones that have shaped the MSG as it exists today and which provide the context for the increase in prominence of the group that has been witnessed since the mid-2000s.

In 1986, the MSG convened for the first time ahead of the meeting of the South Pacific Forum. This was followed in 1988 by the adoption of the Agreed Principles for Cooperation by the leaders of Papua New Guinea, Solomon Islands, and Vanuatu. This took place in Port Vila, which has remained the home of the MSG since then. In 1989, the group's membership increased to include the FLNKS. The MSG adopted what became the precursor to the MSG Trade Agreement (MSGTA) and in 1996 Fiji became the most recent member of the group.

The current renaissance of the MSG commenced in 2007 when the membership signed the Agreement Establishing the Melanesian Spearhead Group (the MSG constitution) and deposited it with the United Nations in order to secure recognition as a sub-regional organisation. In 2008, the MSG's secretariat building (funded by the government of the People's Republic of China) was opened in Port Vila. The contemplation of further economic integration was heralded in 2012 when the leaders of the MSG countries signed an agreement for the Skilled Movement Scheme. In 2013, the MSG celebrated its silver anniversary. Also in this year, an Eminent Persons Group (EPG) undertook a strategic review of the MSG and its secretariat to inform the group's strategy and vision for the next 25 years. It was captured in the 2038 'Prosperity for All' Plan. 


\section{How has the MSG's Underpinning Philosophy Contributed to this Renaissance?}

An underpinning and enduring tenet of the grouping is the commitment to independence for all peoples of Melanesia. This was articulated in the Agreed Principles for Cooperation in 1988 and further restated in the constitution in 2007. This in turn reflected the more radical activist stance of the Melanesian states in relation to continuing decolonisation issues, which set them apart from the more conservative members of the South Pacific Forum, such as Fiji and the Polynesian countries (MacQueen 1989). Until relatively recently, the focus in this regard was on independence for the Kanak people of New Caledonia. The MSG's accommodation of the FLNKS, a political movement whose purpose is to change the sociopolitical status of New Caledonia, is a defining feature of the MSG. The MSG has responsibility for oversight of the implementation of the Noumea Accords and in 2012 established a dedicated unit within its secretariat focused on progressing Kanak self-determination. The secretariat has also facilitated study visits to Timor-Leste for young Kanak professionals who will be expected to take the lead in state-building if and when New Caledonia becomes an independent country (Forau and Newton Cain 2013).

In 2013, the MSG commitment to independence for all Melanesian people was again highlighted when, at the leaders' summit in Noumea, the West Papua National Council for Liberation submitted an application for membership of the group. The process of that application (which has yet to be resolved) provides a telling insight into the complexity of relationships within the MSG and the significance of outside influences on their decision-making.

The issue of self-determination for West Papua is considered in more detail elsewhere in this volume. The issue of the membership application by the United Liberation Movement for West Papua (ULMWP) has yet to be resolved by the MSG. The MSG leaders will consider this application at their 2015 summit in Solomon Islands. The fact that the application is under consideration at all is an indicator of the ability of this group to embrace issues that have proved too diplomatically sensitive or complex for other regional organisations, most notably the Pacific Islands Forum. However, the vexed nature of this issue and the varying relationships between Indonesia and members of the MSG make it an issue that has the potential to severely test the strength of the diplomatic bonds between MSG states. For Webb-Gannon and Elmslie (2014), 'the MSG has reached a turning point and must decide whether it values West Papuan human rights over the potential economic benefits of increasing political engagement with Indonesia'. 
The centrality of Melanesian culture, including tenets of reconciliation and the maintenance of cohesion, was demonstrated by the MSG in how it negotiated the difficult issue of Fiji chairing the group in 2010. Although this issue caused a significant degree of internal division and meant that the MSG was at odds with the Pacific Islands Forum, which had suspended Fiji, the MSG leaders managed to work through their differences and reach an accommodation. The period of Fiji's chairing of the MSG (2010-2013) was one of significant activity. However, it would be simplistic to say that the MSG's renaissance is wholly attributable to the influence of Fiji. As we have already seen, this resurgence commenced prior to 2010 and it is certainly the case that, since 2013, the MSG has continued to be both active and prominent despite a reduction in engagement by Fiji's political leadership. This is largely explained by the increased participation of Papua New Guinea in sub-regional and regional politics and diplomacy, under the leadership of Peter O'Neill (Hayward-Jones and Newton Cain 2014).

\section{What has the MSG Achieved?}

Perhaps the most significant thing the MSG has achieved is a measure of longevity. It celebrated its 25th anniversary in 2013 and has maintained its presence despite a number of challenges arising from internal tensions. Examples include the strained relationship between Papua New Guinea and Solomon Islands during the Bougainville crisis, and friction in 2010 around the controversial decision to allow Fiji to chair the group, even though it was (at that time) under a military dictatorship.

The MSG is the only one of the three sub-regional groups identified previously that has a dedicated secretariat housed in its own building and staffed by a team drawn from its members. Several of the secretariat staff (including the current director-general, Peter Forau) have experience of working at the pan-regional level, especially within the Pacific Islands Forum Secretariat (PIFS). So it is not surprising that some of the sub-regional 'architecture' that the secretariat has built resembles the structures and processes that the PIFS uses. So, for example, the MSG secretariat's work plan for 2015 was reviewed by a senior officials meeting and then endorsed by the foreign ministers meeting. There is also a conference of police commissioners with the potential for similar conferences for chief justices and ombudsmen from within the sub-region.

The MSGTA was signed by Papua New Guinea, Solomon Islands and Vanuatu in 1993, with Fiji acceding to it in 1997. Work on eliminating tariffs on movement of goods between the countries has progressed over time. The agreement and its value to all member countries have recently been reviewed and MSGTA3 is expected to be launched during 2015. In 2012, the group's leaders also signed 
the Skilled Movement Scheme, which is intended to facilitate the free movement of skilled workers between member countries, subject to an upper limit of 400 per country. To date, there has been very little take up of this, especially by the private sector (Voigt-Graf 2015) and there is expected to be more work done on promoting this scheme during 2015.

Based on the success, albeit limited, of the MSGTA, the group is now exploring opportunities for closer economic integration, which may include initiatives such as a customs union and a single currency, both of which have already been considered by officials and political leaders. The group is also looking to explore opportunities for pooled service delivery, including bulk procurement of pharmaceuticals and fuel, and increased and improved shipping services between member countries. All of these initiatives are still at the research stage and one of the characteristics of the approach taken by the MSG is to work closely with the private sector where this is appropriate and more cost-effective (Dornan and Newton Cain 2014).

Recently, the MSG secretariat has shared its experience with another of the sub-regional groupings by assisting in the establishment of the Micronesian Trade Centre and the development of a treaty to create the Micronesian Trade and Economic Community (PINA 2014).

\section{What Does the Future Hold for the MSG?}

Looking ahead, it appears that there are both opportunities and challenges for the MSG.

In the immediate to short term, the issue of most significance is the ULMWP's application for membership. Not only does this issue bring into play individual members' bilateral diplomatic relationships with Indonesia, it also has the potential to be a point of conflict within the group. If the apparent change of position on the part of Papua New Guinea is sustained, this will mark a point of departure from previous dealings where the $\mathrm{O}^{\prime}$ Neill Government and the leadership of Fiji have sought to restrain smaller members' agitation for West Papuan self-determination.

The issue of ULMWP membership points to a related question of how much bigger the MSG is likely to become. Following the pathway established by the Noumea Accords, the French territory of New Caledonia is scheduled to hold a referendum on the transfer of remaining sovereign powers from Paris between now and 2018. In the event that New Caledonia becomes an independent country, it is expected that it will apply to join the MSG. This will not change the number of members, but it will change the nature of the composition and 
will have an impact on funding arrangements for the group, as FLNKS currently does not contribute to costs associated with the secretariat or meetings. Also in play is the 2015-2020 window in which the Autonomous Region of Bougainville will hold a referendum on whether it remains part of Papua New Guinea or secedes. If Bougainville were to become independent (and assuming that it does not choose to become part of Solomon Islands), it is reasonable to expect that it would join the MSG, which would increase the overall membership. It is possible, but not very likely, that the MSG would invite other Pacific Island countries, especially the smaller island states, to become members. The MSG has already made it clear that it sees itself having an important role to play in assisting small island states with solving key development challenges, such as improving transport, but it is not necessary for those countries to be members of the group to be able to benefit from accumulated expertise or new ventures that may be undertaken. If Timor-Leste were to seek to establish closer links with the Pacific Island region, it is possible that the MSG would be its preferred form for doing so. It already has a strong connection with the group, having held observer status since 2011, and the government of Timor-Leste also contributes by way of funding one of the secretariat's positions.

The MSG is expected to play an important role in the ongoing development of Pacific regionalism, including (but not limited to) the rolling out of the Framework for Pacific Regionalism, which resulted from the 2013 review of the Pacific Plan (Pacific Plan Review 2013). The rhetoric put forward at the regional level, most notably by the new Secretary-General of the Pacific Islands Forum Secretariat, is that there is much to be learned from the activities of sub-regional groups, with the work of the MSG at the forefront of that learning (Newton Cain and Taylor 2015). How this rhetoric is applied in practice remains to be seen, but Dame Meg Taylor took the opportunity to visit the MSG secretariat during a recent visit to Port Vila. This is an indication of a refreshed approach from the PIFS, based on recognition of the economic and political significance of the Melanesian sub-region. What appears certain is that the desire for more and better synergy between sub-regional and regional mechanisms forms an important part of what the MSG envisages for itself as encapsulated in its 2038 'Prosperity for All' Plan which arose from the strategic review undertaken in 2013:

Apart from taking full advantage to develop optimally its own economies, the MSG's plan proposes to collaborate and form solidarity with other sub-regional groupings in the Pacific, with the CROP agencies and also to reach out to other PSIDS (Pacific small island developing states) by way of joint development initiatives, e.g. in climate change and fisheries, and to also share with fellow PSIDS burdened with scarcity of resources, the surpluses of its development and economic growth (Tavola 2015). 
Until very recently, the MSG has been very open to approaches from numerous entities, including individual governments, sub-regional and regional organisations, think tanks, and universities. At the leaders' summit in Honiara in mid-2015, the group will adopt the Prosperity for All plan. It is expected that future relationship-building activity on the part of the group, as facilitated by its secretariat, will be more selective and strategic. This could well have significant diplomatic implications, particularly in relation to the granting of observer status. There was a certain amount of internal tension created when Indonesia was granted observer status, and this vexed relationship continues to cause discord (Webb-Gannon and Elmslie 2014). A recurrent issue of interest is what relationship Australia could or should have with the MSG. At the time that the secretariat was established, Australian diplomats came to the conclusion that, as Australia was not a member of the MSG, there was no benefit in providing financial support for the undertaking. To date, Australia has not established any formal relationship with the MSG, and has not requested observer status. Given the Australian government's position regarding the Bainimarama regime prior to the change of government in Canberra in 2013 and the 2014 Fiji elections, this is not surprising. However, it would seem sensible for Australia to establish some relationship with the MSG, given its membership includes countries that are of great economic, strategic and political significance to Canberra. There are indications from within the secretariat that the MSG would be interested in establishing a trade agreement with Australia.

The issue of funding will be an ongoing challenge for the MSG. The group has benefitted from the support of numerous donors including the government of the People's Republic of China and the European Union. However, ensuring that the member governments pay their share of ongoing costs, which are calculated by reference to relative population size, is a perennial challenge. Very recently, the group announced the creation of 'Melanesian Solutions', which is a consulting operation whose income will fund overheads and operational costs including those associated with maintenance of the secretariat.

Reference has already been made to the fact that numerous members of the secretariat (including the current director-general) have a pedigree that includes working at the pan-regional level, most notably within the PIFS. Critics of the MSG point to the apparent replication of PIFS mechanisms and methodologies. A real risk to the credibility of the MSG, therefore, is that it follows the PIFS and becomes too secretariat-centric. To maintain credibility, it needs to proactively maintain its focus on delivering real outcomes that benefit the populations of its member countries. 


\section{Conclusion}

The commencement of the recent renaissance of the MSG predated the change of chairing arrangements in 2010 which saw the then interim prime minister of Fiji use this mechanism as a key plank in his assertive development of new diplomatic and political relationships as a reaction to his country's suspension from the Pacific Islands Forum. Some may have expected that MSG activity would wane once Fiji relinquished the chair of the group in 2013. This has proved not to be the case, partly because of the increased, and increasing, prominence of Papua New Guinea as a sub-regional and regional leader. The momentum around membership of West Papua has also maintained a focus on the MSG's ability and willingness to be diplomatically innovative.

The diplomatic importance of the MSG is likely to increase and alongside it there will be internal and external challenges. The group has already demonstrated a certain degree of resilience in relation to previously arisen challenges and it is to be expected that this will provide a bedrock of strength and experience to overcome future obstacles.

\section{References}

Asian Development Bank (ADB), 2014, 'Pacific Economic Monitor'. Available at: www.adb.org/sites/default/files/publication/149735/pem-december-2014. pdf.

Dornan, M. and T. Newton Cain, 2014, 'Regional Service Delivery Among Pacific Island Countries: An assessment', Asia and the Pacific Policy Studies 1(3), pp. 541-60.

Forau, P. and T. Newton Cain, 2014, 'Peter Forau on Why the Melanesian Spearhead Group is a Success', Devpolicy, 5 March. Available at: devpolicy.org/peterforau-on-why-the-melanesian-spearhead-group-is-a-success-20130305/.

Hayward-Jones, J. and T. Newton Cain, 2014, 'Pacific Island Leadership: PNG steps up', The Interpreter. Available at: www.lowyinterpreter.org/post/2014/08/28/ Pacific-island-leadership-PNG-steps-up.aspx COLLCC $=3972002704 \&$.

MacQueen, N., 1989, 'Sharpening the Spearhead: Subregionalism in Melanesia', Pacific Studies 12(2), pp. 33-52. 
Newton Cain, T. and M. Taylor, 2015, 'Regionalism, Sub-Regionalism and Women's Empowerment: An interview with Dame Meg Taylor', Devpolicy. Available at: devpolicy.org/regionalism-sub-regionalism-and-womens-empowerment-aninterview-with-dame-meg-taylor-20150308/.

Pacific Islands News Association (PINA), 2014, 'MSG Helps Micronesian States on Endeavour Towards Closer Economic Integration', 30 September. Available at: www.pina.com.

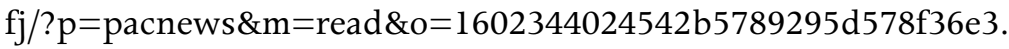

Pacific Plan Review, 2013, 'Report to Pacific Leaders', Pacific Islands Forum Secretariat, Suva, Fiji. Available at: www.cid.org.nz/assets/Key-issues/ Pacific-development/Pacific-Plan-Review-2013-Volume-1.pdf.

Radio New Zealand, 2015, 'Polynesian Leaders Meet in Auckland', 3 February. Available at: www.radionz.co.nz/international/pacific-news/265126/ polynesian-leaders-meet-in-auckland.

Tavola, K., 2015, 'MSG's Opportunity to Direct Pacific Regionalism to New Heights', Pacific Institute of Public Policy, 3 March. Available at: pacificpolicy. org/2015/03/msgs-opportunity-to-direct-pacific-regionalism-to-greaterheights-2/.

Voigt-Graf, C., 2015, 'Melanesians on the move', Devpolicy, 2 February. Available at: devpolicy.org/melanesians-on-the-move-20150202/.

Webb-Gannon, C. and J. Elmslie, 2014, 'West Papuan Heartache?: Indonesia's Melanesian foray', The Asia-Pacific Journal 12(47). 
This text is taken from The New Pacific Diplomacy, edited by Greg Fry and Sandra Tarte, published 2015 by ANU Press, The Australian National University, Canberra, Australia. 